\title{
Creating a Space for YAL with LGBT Content in Our Personal Reading:
}

\author{
Creating a Place for LGBT Students in Our Classrooms
}

A

dolescent literature is a source of both information and validation for today's teenagers. As Adrian Fogelin revealed in her 2006 ALAN address, "Opening Middle School Minds with Young Adult Literature," these texts act as "mirrors" for readers who face challenges like those faced by characters in the texts and as "windows" for readers who don't. Young adult literature (YAL) with lesbian, gay, bisexual, and transgender (LGBT) content is no exception. For teens who are questioning their sexual orientation or gender identity and for those who are out and proud, YAL with LGBT content can affirm their experiences. For teens who conform to the privileged heterosexual standard and who follow traditional gender expression norms, these texts provide an opportunity to empathize with the LGBT characters whose lives often take very different paths from their own.

According to the 2005 Gay, Lesbian \& Straight Education Network (GLSEN) National School Climate Survey, LGBT students continue to face verbal and physical harassment in schools because of their sexual orientation or gender expression. Of the 1,700 respondents to the 2005 survey, " $64.3 \%$ reported feeling unsafe at school because of their sexual orientation specifically, and $40.7 \%$ felt unsafe because of how they expressed their gender" (Kosciw and Diaz xiii). Clearly, a significant number of LGBT students do not feel they have a place in our schools where they can truly be themselves.

These statistics hit a little closer to home for me when an incident occurred at a school where one of my students was completing student teaching/field experience. After an alleged attack by one student on another, school disciplinary action resulted in a tenday suspension. Serious injury and hospitalization were involved, along with the implication that the alleged attack was motivated by issues of sexual orientation. The student teacher could not help but include this incident in the required reflections on the daily experience of being in the classroom. The incident was obviously disturbing for this aspiring professional, but we can only imagine how LGBT students at this particular school must have felt.

Even more pervasive than physical violence is the verbal harassment that occurs in schools when students-and teachers-make homophobic remarks such as "faggot" or "dyke" or "that's so gay." Only $16.5 \%$ of the respondents to the GLSEN National School Climate Survey claimed that faculty and staff intervened when they heard such remarks, while over $18 \%$ claimed that they had heard teachers themselves use that type of language (Kosciw and Diaz xiii). What are we teaching students when we downplay or ignore acts of hate and prejudice? What are we teaching them when we participate in these acts? 
As teachers, we must initiate positive changes in our classroom communities regarding differences in sexual orientation and gender expression. For English Language Arts teachers in particular, YAL with LGBT content is one avenue to instigate those changes.

\section{In-service and Pre-service Teachers' Perspectives on YAL with LGBT Content}

In order to learn more about pre-service and inservice teachers' perspectives on the value of YAL with LGBT content, I conducted a survey in fall 2007. My participants included 21 pre-service English teachers from Kennesaw State University's undergraduate and masters programs in English Education and 51 middle and high school English teachers in suburban school districts near Atlanta. The survey asked participants to rate the importance of their own awareness and use of YAL with LGBT content in the classroom and provided space for participants to list titles of YAL with LGBT content that they have read, those they (plan to) recommend to students, and those they (plan to) incorporate into their curriculums. Finally, the survey encouraged participants to express their concerns about teaching YAL with LGBT content.

The level of importance participants placed on their own awareness and use of YAL with LGBT content decreased as the stakes grew higher-from being familiar with these texts to actually including them in the curriculum. Over $42 \%$ of participants claimed that it is somewhat important for them to be familiar with YAL with LGBT content. Thirty-six percent claimed that it is somewhat important for them to be able to recommend YAL with LGBT content to students, and just $27 \%$ claimed that it is somewhat important for them to incorporate YAL with LGBT content into their curriculum and teaching, with over $56 \%$ claiming that teaching YAL with LGBT content is not important at all (See Table 1).

Not surprisingly, the respondents who were most adamantly against the use of YAL with LGBT content were also the ones who were least likely to have read any of those texts themselves. Less than half of the participants (47\%) claimed to have read at least one YA novel with LGBT content, with some of the remaining $53 \%$ responding with strongly-worded answers, such as this one from a veteran teacher: “Absolutely none! Don’t intend to either!!! Our young people are bombarded by this crap in the media and I intend to keep it out of my classroom as long as I teach!!!" Clearly this topic is one for which people feel a moral obligation to state and defend their beliefs vigorously.

Not all of the participants had such a negative opinion about YAL with LGBT content. In fact, $23 \%$ expressed their concerns about teaching these texts in a way that I characterized as open-minded and insightful. Two participants expressed no concerns related to the literature itself but instead noted issues of time and respect.

[I have] the same concerns I have with all literature-carving out enough time to do the work justice.

I have no concerns. I feel that discussing things that are

Table 1. Teacher attitudes toward YA literature with LGBT content

How important is it for you, as a (pre-service or in-service) teacher, to . . .

(A) be familiar with YAL with LGBT content?

(B) be able to recommend YAL with LGBT content to students?

(C) incorporate YAL with LGBT content into your curriculum and teaching?

\begin{tabular}{|l|c|c|c|}
\hline Answer Options & $\begin{array}{l}\text { Response Percent for } \\
\text { Question A }\end{array}$ & $\begin{array}{l}\text { Response Percent for } \\
\text { Question B }\end{array}$ & $\begin{array}{l}\text { Response Percent for } \\
\text { Question C }\end{array}$ \\
\hline Very important & $18.57 \%$ & $21.74 \%$ & $8.70 \%$ \\
\hline Somewhat important & $42.86 \%$ & $36.23 \%$ & $27.54 \%$ \\
\hline Not important & $30.00 \%$ & $37.68 \%$ & $56.52 \%$ \\
\hline I don't know. & $8.57 \%$ & $4.35 \%$ & $7.25 \%$ \\
\hline
\end{tabular}


difficult to talk about is part of our responsibility as educators. However, I do feel that before teaching anything with LGBT content as well as racial issues the students and teachers must have a common respect for one another in their classroom community as well as have an understanding of proper "etiquette" when discussing topics such as this. Introducing LGBT content through YAL is a very effective way to lead into discussion.

Other participants noted the importance of YAL with LGBT content for a democratic and culturally responsive classroom.

I believe that young adults would benefit from reading literature that describes many lifestyles, preferences, and character types/situations.

I am aware that to make students more accepting we must increase interaction with things that seem different.

My emphasis in teaching literature is on broadening one's horizon, so I think teaching literature with LGBT content would be very valuable. I would be very careful with the way I went about it, so I would be concerned with my ability to effectively lead conversations on the subject matter. It is hard enough to teach Of Mice and Men and to get the students to respectfully discuss the mentally disabled character, Lennie. It would be a challenge but I think it would be a very valuable challenge.

One participant explained that a lack of listening on the part of administrators, parents, students and other teachers is a concern.

Too often it appears that people are merely waiting for a specific word, a phrase, or an attitude to pounce on without ever taking into consideration the true meaning of what an individual is really trying to say.

These teachers have justifiable concerns, and, judging by the vehement responses from other survey participants, rightfully so. They will most certainly have colleagues challenging them every step of the way in their attempts to ensure that "GLBTQ [gay, lesbian, bisexual, transgender, queer/ questioning] students . . . have the same opportunities as are accorded to heterosexual students to discuss issues important to their identities as GLBTQ people, to learn about GLBTQ people in history, to learn about the GLBTQ community and their struggle for civil rights, and to go to school without fear of being harassed, tortured, or killed” (MacGillivray 315).

\section{Misconceptions about YAL with LGBT Content}

Although nearly a quarter of the participants' responses indicated a sense of appreciation of YAL with LGBT content, many others' responses indicated little tolerance for LGBT people and literature. Perhaps it is teachers' unfamiliarity with the texts that contributes to their concern and/or negative attitudes. A veteran teacher who had not read any YAL with LGBT content made this remark:

It is not appropriate for literature and composition teachers to discuss sexuality with students. To say otherwise is disgusting and appalling. The idea to make the classroom more "PC" is talking absolute stupidity. If a gay student needs books with this theme, they may speak with the media specialist.

Naturally, teachers who have not read these texts might have misconceptions about their content. The above participant went on to respond to another prompt:

It is not the classroom teacher's responsibility or purpose to discuss sex with students-heterosexual or homosexual. As far as literature is concerned, themes of love and devotion come up and those themes are approached.

This participant seemed to equate discussions of sex with the inclusion of YAL with LGBT content. The idea that YAL with LGBT content only focuses on the sexual lives of the characters was a common perception among participants who opposed these texts. Do YA novels that depict heterosexual relationships-either for the young people featured in the book or the adult characters (i.e. parents) always focus on their sexual lives? Certainly not. The same is true of YAL with LGBT content. For example, Julie Anne Peters' Between Mom and Jo features a male protagonist, Nick, whose lesbian moms separate, forcing him to stay with his birth mom because the law offers no protection to his other mom without proof of adoption. 


\section{It is not a question of}

whether or not we want

students to think about,

talk about, or act on their

feelings and uncertainties.

They most certainly will.

We can either deny our

students' physical, cogni-

tive, and emotional devel-

opment, or we can ac-

knowledge it and prepare

ourselves to respond

appropriately and com-

passionately to their

needs.
Peters' novel Luna depicts the experiences of fifteenyear-old Regan who struggles to support her older brother as he transitions from male to female. Boy Girl Boy by Ron Koertge depicts the lives of three teenagers on the verge of high school graduation who are trying to come to terms with their identities.

The argument that students shouldn't be making discoveries about their sexuality was also a popular response in this survey. One pre-service teacher, who claimed to have read one YA novel with LGBT content (Ironman by Chris Crutcher) expressed this concern:

A YA text exploring LBGT content is essentially a book exploring the sexual lives of

its characters. I don't believe students-especially middle school or early high school-should be making many discoveries about their sexuality (gay or straight); I don't want to think of my students as sexual beings, I guess.

Regardless of whether or not we want students to explore their own sexuality, adolescence is "characterized by a need to establish sexual identity through becoming comfortable with one's own body and sexual feelings" ("Adolescent Development"). In fact, data from the biennial GLSEN National School Climate Surveys, conducted since 1999, reveal that adolescents as young as twelve years old are identifying themselves as LGBT ("FAQs"). It is not a question of whether or not we want students to think about, talk about, or act on their feelings and uncertainties. They most certainly will. We can either deny our students' physical, cognitive, and emotional development, or we can acknowledge it and prepare ourselves to respond appropriately and compassionately to their needs.

\section{Can Students Handle It?}

Twenty-seven percent of the participants expressed concerns about student maturity and reactions to YAL with LGBT content.

While I can certainly see the value of suggesting young adult literature with LGBT content to students on a list of possible choices, I doubt I would ever include a selection for the entire class to read. I prefer to stick with the universal themes found in the classics. If selected, introduced, discussed, and taught well, students still love the classics. When I have used essays or magazine articles that include LGBT, they often make many students unnecessarily uncomfortable.

With the student populations I've seen, any reference to homosexuality has the potential to turn ugly, which would be difficult to avoid without seeming to promote one lifestyle or the other.

I imagine most adolescents are not exactly ready to discuss and confront LGBT content on a mature level.

Are adolescents capable of discussing LGBT content on a mature level? Well, they are certainly capable of confronting LGBT content on an immature level, judging by the insults and harassment that occur regularly in public schools. Might we consider helping them to address it with more care and respect? Is that not part of our role as teachers-asking students to consider alternative viewpoints thoughtfully, encouraging them to think critically about their own assumptions, discussing and modeling for them how to listen carefully and disagree respectfully?

\section{What Values Should Schools and Teachers Teach?}

Several participants expressed concern about how they would be perceived as teachers for including YAL with LGBT content in their curriculums. A veteran teacher who claimed to see no importance in being familiar with or sharing these texts with her students had this to say:

I absolutely feel that a student's sexual orientation is clearly none of my business as a classroom teacher, and I feel that making decisions based on this aspect of the literature is tantamount to bringing one's personal political agenda into the classroom. I consider that unethical.

This participant's response reveals another common rationale for avoiding texts with LGBT content-that 
teachers should not be made aware of their students' sexual orientations. Yet, how many of us simply assume that our students are heterosexual? It's an easy assumption to make because we've not challenged ourselves to do otherwise. We live in a society in which heterosexuality and traditional gender roles are assumed, and we demonstrate these assumptions in our interactions with our students and in the texts we share with them. A 2004 national poll conducted by GLSEN revealed that "approximately $5 \%$ of American high school students identify as lesbian or gay," which averages out to at least one student per classroom ("FAQs"). Clearly, our assumptions need to change.

This participant also equates the "bringing [of] one's personal political agenda into the classroom" with the teaching of YAL with LGBT content. This begs the question: to use this participant's logic, isn't the absence of texts with LGBT content and the inclusion of texts that only represent heterosexual relationships and traditional gender norms simply another way to bring our political agendas to the classroom? Aren't our political agendas pretty evident based on the content we choose to include in our curriculum design?

According to MacGillivray, it is impossible for educators to avoid teaching values since " $[t]$ hey do so even by default, because they reinforce the status quo" (316). By avoiding the subject, teachers indirectly impose a set of values that ignore, devalue, and silence LGBT students. Imagine what it must feel like for a gay, lesbian, bisexual, or questioning student to see only heterosexual relationships represented in classroom texts and discussions. Imagine, too, what it must feel like for a student who is questioning his/her gender identity to see only traditional gender roles/ expressions represented in those same texts and discussions. Regardless of our political agendas and personal beliefs we have an obligation to our students as we prepare them to be democratic citizens who are capable of valuing one another as such, not people who judge one another based on any number of uncontrollable qualities.

It is also important to note that "simply discuss[ing] different sexual orientations and gender identities in a classroom does not imply that a teacher must teach one over another or approve more highly of one over another" (MacGillivray 317). Indeed, incorporating YAL with LGBT content into our curricu- lums does not indicate that we are trying "to force one's views upon children in their formative years," as one participant put it. Rather, it demonstrates to our students that these texts-these people, our studentsare valued.

\section{Can Parents and Administrators Handle It?}

By far the most pressing issue for in-service and pre-service teachers in relation to teaching YAL with LGBT content was the reaction of parents and administrators. Forty-seven percent claimed that parents and administrators were a concern. Some teachers recalled negative experiences when members of these groups became critical of their text selections.

Once I did The Color Purple with my Honors 10th grade, and there was a lot of misunderstanding. Later the book was put behind locks in the library, and now the seniors can choose it for independent reading but have to have parental consent. That's how conservative we are here.

I don't think the sexual orientation of anyone else is my business, and I work in a very conservative county. I'd have a hundred parents lined up outside the principal's office. I got called in several years ago for reading Staying Fat for Sarah Byrnes by Chris Crutcher.

Teachers who are concerned about administrative and parental reactions would do well to investigate district and school policies pertaining to sexual orientation and gender identity/expression:

- Does the school have non-discrimination and sexual harassment policies in place that explicitly include sexual orientation and gender identity/ expression?

- Does the school provide resources and training for faculty, staff, and students about sexual orientation and gender identity/expression and to combat antiLGBT bullying and harassment? 
- Does the state have legislation that supports these initiatives? ("PFLAG")

Regardless of the answers to these questions, however, teachers can and should increase their own awareness of the LGBT community by reading texts that feature LGBT characters and content. This includes YAL.

\section{Creating Space for YAL with LGBT Content in our Personal Libraries}

These in-service and pre-service teachers have the same concerns that I did when I taught middle school. They have the same concerns I have now, as I prepare future English teachers to negotiate the complexities of planning for and managing their own English Language Arts classrooms. In my university classroom, I have a great deal more freedom to encourage discussion about the need for teachers to include a range of texts in the curriculum, but if I were to return to the secondary classroom, I would still face these obstacles. My writing of this piece is an attempt to begin articulating these concerns and developing a plan of action for myself and for my audience.

Maybe one purpose of YAL with LGBT content is to educate teachers: to help us empathize with students (and colleagues) who may be questioning their own sexual orientation or gender identity; to help us become informed, comfortable, responsible, and courageous in our responses to homophobic and gender stereotypic comments and slurs; to help us create a classroom and school environment in which students feel they have a sense of place and where they can express themselves fully. Perhaps, this is the first step for us: simply reading the texts ourselves. Particularly for teachers who feel that their hands are tied by administrative and parental restrictions, maybe the first step is to simply make ourselves more aware of the quality adolescent literature available that features LGBT characters.

Last semester I participated in a book club for a text called Inspiration for LGBT Students \& Their Allies. This text contains essays, poems, and drawings by LGBT students and their advocates. For the first time in my life I began thinking about what it means for someone to question his/her gender identity and to express his/her gender differently from the traditional means of doing so. I began to think about the importance of addressing not just sexual orientation in our curriculums, but also gender identity/expression as we try to help all students feel safe and affirmed in our classrooms, schools, and society. This has led me to YA texts like Luna by Julie Anne Peters, What Happened to Lani Garver by Carol Plum-Ucci, Parrotfish by Ellen Wittlinger, and "The Wrong Body" by Claiborne Smith. It has also led me to non-fiction texts such as Transparent: Love, Family, and Living the T with Transgender Teenagers by Cris Beam, which chronicles the lives of four male-to-female transgender teens in Los Angeles.

As a middle school teacher, I recall having frank discussions with my students about the need to respect people's sexual orientation and refrain from using the "that's so gay" slur, but I don't ever recall discussing gender identity and gender expression with them. Somehow, that part of the LGBT acronym was off my radar. I didn't even know what transgender meant, let alone how to reflect on my own words and actions to try to make sure that I was not referring exclusively to traditional gender roles in my instruction and in my informal interactions with students.

The only text we read that had any type of LGBT content was If You Come Softly by Jacqueline Woodson, which features a protagonist whose sister is a lesbian. The homosexuality is not the issue or problem in the story; the two protagonists' interracial relationship is. But I distinctly remember my students tittering uncomfortably at the mention of a lesbian relationship. I recall that we didn't spend much-if any-time talking about it; I wanted to wait for student questions, and none came, so it just became the elephant in the room that nobody mentionedincluding me. I let Woodson do the talking for us. Why? Because I had the same concerns that my survey participants have: I didn't have the confidence or knowledge to facilitate a discussion about LGBT issues, and I didn't know how to respond to negative responses from students, parents, colleagues, and administrators.

I still don't know exactly how to address these concerns except that avoiding them by excluding LGBT content from the curriculum is no longer an option. The fact is, some of our students will question their gender identities. They will question their sexual orientations. Whether or not they confide in us is another story. But shouldn't we be concerned about making sure that our classrooms aren't just safe 
spaces for the students who conform to the traditional gender and sexual roles? Should we not educate ourselves and, in turn, educate our students about the importance of respecting and appreciating our differences, rather than using them as weapons to hurt, humiliate, and exclude-either intentionally or unintentionally?

MacGillivray argues that the inclusion of LGBT content in the curriculum "can help to destigmatize nonheterosexual identities and can deconstruct gender role stereotypes that limit all students" (305). This content doesn't just benefit our LGBT students, it benefits all of our students since " $[\mathrm{t}]$ he fear of being perceived as gay restricts boys to making choices that will affirm what it means to be a man in our society and restricts girls to making choices that will affirm what it means to be a woman" (MacGillivray 305). By not including texts with LGBT content in our curriculums, or at the very least in our personal or classroom libraries, we risk reinforcing gender role stereotypes and a culture of heteronormativity, which ultimately excludes LGBT teens from the community of learners who feel valued and whose values are reflected in our classrooms and schools.

\section{Recommended Reading: YAL with LGBT Content}

While I'm certainly not an expert, below I have shared some texts that I've read, enjoyed, and learned from. If you've not done so already, consider reading these recent YA texts with LGBT content in order to better equip yourself to be a more reflective, compassionate, and knowledgeable teacher. If you've already read them, take a look at young adult author Lee Wind's blog at http://www.leewind.org/. In it, Wind attempts to create "as inclusive and thorough a resource as possible for finding out about all the YA books out there with GLBTQ characters and themes!” (Wind). His blog could also be an excellent resource for your students and your media specialist.

Koertge, Ron. Boy Girl Boy. Orlando: Harcourt, 2005. Levithan, David. The Realm of Possibility. New York: Random House, 2004.

Peters, Julie Anne. Between Mom and Jo. New York: Little, Brown, and Co., 2006.
Peters, Julie Anne. Keeping You a Secret. New York: Little, Brown, and Co., 2003.

Peters, Julie Anne. Luna. New York: Little, Brown, and Co., 2004.

Plum-Ucci, Carol. What Happened to Lani Garver. Orlando: Harcourt, 2002.

Sanchez, Alex. Rainbow Boys. New York: Simon \& Schuster, 2001.

Shimko, Bonnie. Letters in the Attic. Chicago: Academy, 2002.

Smith, Claiborne. "The Wrong Body." Rush Hour: A Journal of Contemporary Voices. Vol. 3. Ed. Michael Cart. New York: Delacorte, 2005. 135-151.

Watts, Julia. Finding H.F. Los Angeles: Alyson Books, 2001. Wittlinger, Ellen. Parrotfish. New York: Simon \& Schuster, 2007.

Woodson, Jacqueline. From the Notebooks of Melanin Sun. New York: Scholastic, Inc., 1995.

\section{Note}

1 "Transgender is an umbrella term-used to catch anybody who looks or acts outside the bounds of traditional gender norms” (Beam 15).

Katherine Mason is an assistant professor of English Education at Kennesaw State University in Georgia.

\section{Works Cited}

"Adolescent Development." MedlinePlus Medical Encyclopedia. 19 Sept. 2007. 9 Oct. 2007 http://www.nlm.nih.gov/ medlineplus/ency/article/002003.htm

Beam, Cris. Transparent: Love, Family, and Living the T with Transgender Teenagers. Orlando: Harcourt, 2007.

D’Angelo, Anthony J., Stephen D. Collingsworth, Jr., Mike Esposito, Gabriel Hermelin, Ronni Sanlo, Lydia A. Sausa, and Shane L. Windmeyer. Inspiration for LGBT Students \& Their Allies. Easton, PA: The Collegiate EmPowerment Company, 2002.

"FAQs: Top 5 Frequently Asked Questions from the Media." Gay, Lesbian \& Straight Education Network. 12 Oct. 2007 http:// www.glsen.org/cgibin/iowa/all/news/record/1970.html

Kosciw, J.G. and E.M. Diaz. The 2005 National School Climate Survey: Executive Summary. New York: GLSEN, 2006. 10 Oct. 2007 http://www.glsen.org/binary-data/GLSEN_ATTACH MENTS/file/585-1.pdf

MacGillivray, Ian K. "Educational Equity for Gay, Lesbian, Bisexual, Transgendered, and Queer/Questioning Students: The Demands of Democracy and Social Justice for America's Schools." Education and Urban Society. 32.3 (2000): 303323.

"PFLAG Olympia Schools Assessment." Parents, Families \& Friends of Lesbians \& Gays (PFLAG). 12 Oct. 2007 http:// pflag.org/Olympia_School_Assessment.1052.0.html

Wind, Lee. "I'm Here. I'm Queer. What the Hell Do I Read?" 11 Oct. 2007 http://www.leewind.org/ 